\title{
MEMAKMURKAN BUMI DALAM PERSPEKTIF TEOLOGI PENDIDIKAN
}

\author{
Husnul Amin \\ Sekolah Tinggi Ilmu Tarbiyah Raudhatul Ulum Sakatiga \\ Email: amin_husnul@yahoo.co.id
}

\begin{abstract}
Abstrak
Kehadiran manusia di muka bumi ini, tiada lain adalah untuk beribadah kepada Allah. Demikianlah kehendak Allah sebagai pencipta manusia, Allah menciptakan manusia agar melakukan pengabdian kepadaNya, bentuk pengabdian yang dimaksud bukan saja dengan melaksanakan ibdah mahdhah melainkan juga ghairu mahdah yang kesemuanya itu diperuntukkan untuk mencari ridho Allah SWT. Seperti halnya kewajiban memakmurkan dunia di mana manusia telah Allah anugerahkan berbagai macam fasilitas yang terhamr dimuka bumi ini untuk dikelolanya karena manusia adalah khalifatullah, semua itu bukan untuk kepentingan Allah, akan tetapi justru untuk kepentingan manusia itu sendiri. Agar terwujud tugas pemakmuran dunia yang maksimal, maka dibutuhkan sumber daya manusia yang terdidik, dan cara satu-satunya adalah dengan pendidikan, diperlukan pendidikan untuk menopang kualitas sumber daya tersebut, selanjutnya pada akhirnya manusia mampu memajukan dunia, memakmuran dunia dengan memunculkan penemuan-penemuan yang baru di segala bidang yang akan dibutuhkan oleh generasi setelanya yang relevan dengan waktu dan tempat, dan hal tersebut telah dibuktikan manusia dari masa kemasa yaitu dengan semakin banyaknya penemuan terbaru di segala bidang, lebih-lebih pada sektor teknologi dan pendidikan.
\end{abstract}

Kata Kunci: Isti'marul Ardh, Ta'riful Insan, Pendidikan

\section{Pendahuluan}

Pembahasan Isti'marul Ardh (memakmurkan bumi) atau biasa diterjemahkan dengan memakmurkan dunia adalah merupakan bagian dari tujuan diciptakannya manusia di muka bumi ini, Allah SWT telah menegaskan dalam beberapa ayat al Qur'an adanya tugas manusia untuk memakmurkan bumi ini. Sadar akan tujuan hidupnya di dunia, maka manusia sebagai khalifah di muka bumi berusaha sekuat tenaga dengan potensi yang dimilikinya untuk mengola segala fasilitas yang Allah berikan untuk memajukan kehidupan dunia dalam berbagai macam bidang. Pemakmuran bumi atau dunia bukan hanya saja pada bidang pertanian, atau teknologi dan lainnya, namun juga pada bidang pendidikan.

Untuk memudahkan dalam memahami tulisan ini, maka penulis akan memulai tulisan makalah ini dengan membahas tentang Ta'ri-ful Insan (definisi manusia) menurut islam, hakekat manusia, tujuan hidup, serta tugas dan fungsi manusia dalam memakmurkan bumi dan selanjutnya kaitannya dengan masalah pendidikan. 


\section{Memakmurkan Bumi dalam Perspektif Teologi Pendidikan \\ Husnul Amin}

\section{Definisi manusia dan Hakekat Penciptaannya}

Dilihat dari asal penciptannya, manusia tersusun dari unsur bumi dan unsur langit. Unsur bumi karena manusia diciptakan dari tanah. Unsur langit karena setelah proses penciptaan fisiknya sempurna, Allah meniupkan ruh kepadanya, sebagaimana firman Allah yang artinya :

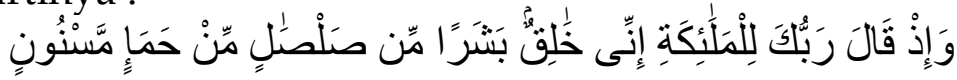

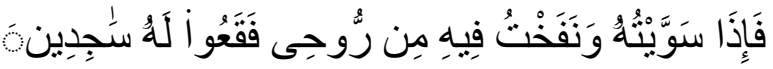

Dan (ingatlah), ketika Tuhanmu berfirman kepada para malaikat: "sesunggunya Aku akan menciptakan seorang manusia dari tanah liat kering (yang berasal) dari lumpur hitam yang diberi bentuk, (QS.Al-Hijr : 28-29)

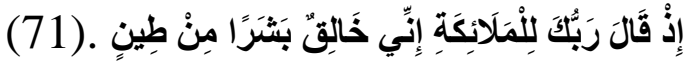

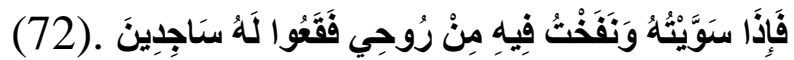

Maka apabila Aku Telah menyempurnakan kejadiannya, dan Telah menipukan kedalamnya ruh, (ciptaan)-Ku, Maka Tunduklah kamu kepadanya dengan bersujud(QS.Shod :71-72)

Allah menciptakan manusia pertama Adam AS langsung dari tanah, sesudah itu Allah menciptakan keturunannya dari sari pati tanah, sari pati dari tanah yang merupakan bahan dasar jasad manusia keturunan Adam AS adalah air mani yang dalam al Quran disebut sebagai air hina, oleh karena itu, mengingat akan asal penciptannya manusia tidak pantas dalam hidup untuk menyombongkan dirinya, sebagaimana Firman Allah yang artinya:

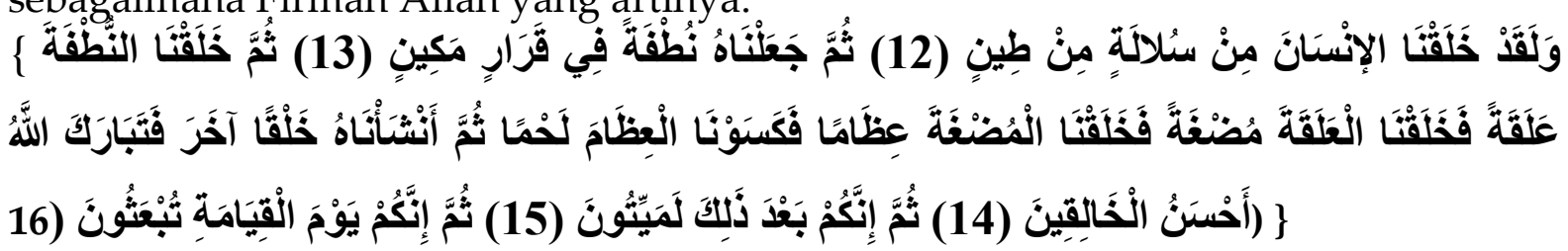

Dan Sesungguhnya kami telah menciptakan manusia dari suatu saripati (berasal) dari tanah. Kemudian kami jadikan saripati itu air mani (yang disimpan) dalam tempat yang kokoh (rahim). Kemudian air mani itu kami jadikan segumpal darah, lalu segumpal darag itu kami jadikan segumpal daging, dan segumpal daging itu kami jadikan tulang belulang, lalu tulang belulang itu kami bungkus dengan daging.Kenudian kami jadikan dia makhluk yang (berbentuk) lain. Maka Maha sucilah Allah, Pencipta yang paling baik. Kemudian, sesungguhnya kamu sekalian akan dibangkitkan (dari kuburmu) di hari kiamat.(QS:AlMukminun :12-16)

Dan disebutkan dalam ayat lain yang artinya :

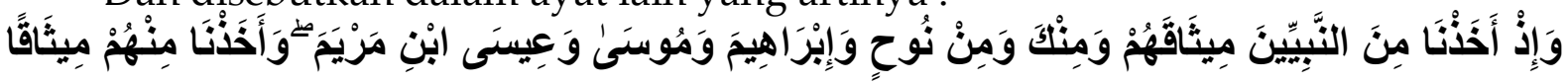

غَلَّيظًا

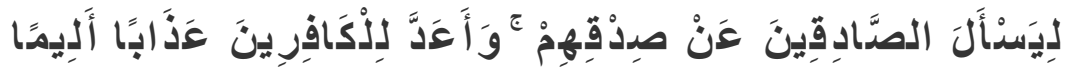

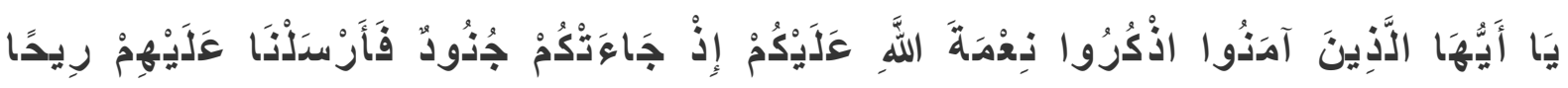

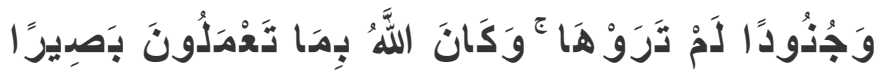


RAUDHAH Proud To Be Professionals Jurnal Tarbiyah)damiyah

Volume 3 Nomor 2 Edisi Desember 2018

P-ISSN : 2541-3686

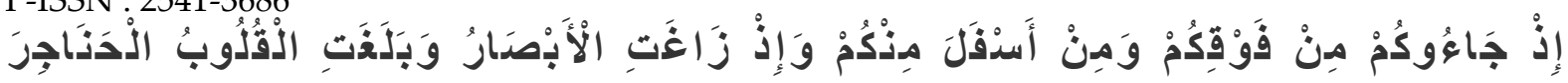

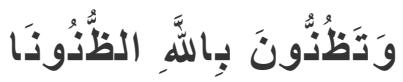

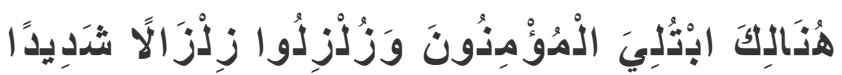

Yang membuat segala sesuatu yang dia ciptakan sebaik-baiknya dan yang memulai penciptaan manusia dari tanah. Kemudian dia menjadikan katurunannya dari saripati air hina. Kemudian dia menyempurnakan dan meniuokan ke dalamnya roh (ciptaan)-Nya dan dia menjadikan bagi kamu pendengaran, penglihatan dan hati; (tetapi) kamu sedikit sekali bersyukur. Dan mereka berkata: "Apakah bila kami Telah lenyap (hancur dalam tanah, kami benar-benar akan berada dalam ciptaan yang baru [1191]?" bahkan mereka ingkar akan menemui tuhannya. Katakanlah: "Malaikat maut yang diserahi untuk (mencabut nyama)mu akan mematikanmu, kemudian Hanya kepada Tuhanmulah kamu akan dikembalikan." Maksudnya dihidupkan kembali untuk menerima balasan Tuhan pada hari kiamat(Qs. A1-

Azhab : 7-11)

Dan dalam ayat lain yang artinya :

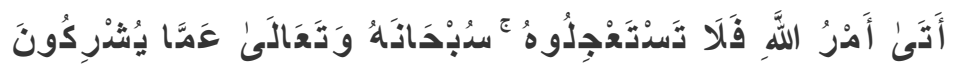

Telah pasti datangnya ketetapan Allah Maka janganlah kamu meminta agar disegerakan (datang) nya. Maha Suci Allah dan Maha Tinggi dari apa yang mereka persekutukan(QS.alNahl : 1)

Dan dalam ayat lain yang artinya :

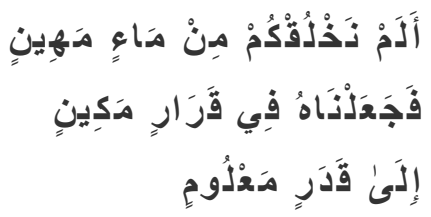

Bukankah kami menciptakan kamu air yang hina [1540]? Kemudian kami letakkan dia dalam tempat yang kokoh (rahim), Sampai waktu yang ditentukan(Qs. Al-Mursalat : 20-22)

Dari dua unsur itu, berdasarfungsinya manusia disimbolkan dengan tiga unsur utama yaitu hati, akal, dan jasad ${ }^{1}$

Dari pejabaran yang ada dalam al Quran bahwa manusia dapat didefinisikan sebagai makhluk yang terdiri dari ruh, akal dan jasad yang dimuliakan Allah dengan tugas beribadah dan berkedudukan sebagai khalifah atau wakil Allah di Bumi, sebagaimana yang Allah SWT firmankan dalam ayat-ayatNya berikut yang artinya :

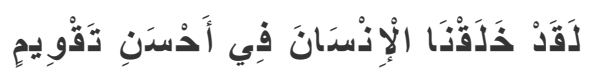

Sesungguhnya kami telah menciptakan manusia dalam bentuk yang sebaikbaiknya(Qs, Al-Thien : 4)

Begitu pula disebutkan dalam ayat lain yang artinya :

\footnotetext{
${ }^{1}$ Jasiman’Syarah Rasmul Bayan Tarbiyah’ Auliya Press solo, cet. 1, hal. 163 Surakarta, 2005.
} 


\section{Memakmurkan Bumi dalam Perspektif Teologi Pendidikan}

\section{Husnul Amin}

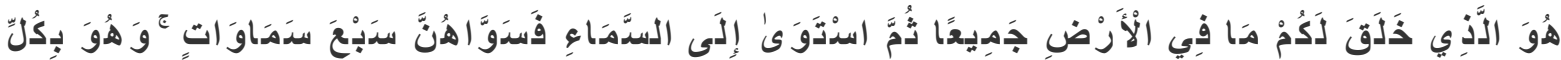

$$
\begin{aligned}
& \text { شَيْيٍِْ عَلِّلِمُ }
\end{aligned}
$$

Dia-lah Allah, yang menjadikan segala yang ada di bumi untuk kamu dan dia berkehendak (menciptakan) langit, lalu dijadikannya-Nya tujuh langit. Dan dia Maha Mengetahui segala sesuatu(Qs. Al-Baqarah : 29)

Dalam surat lain disebutkan yang Artinya :

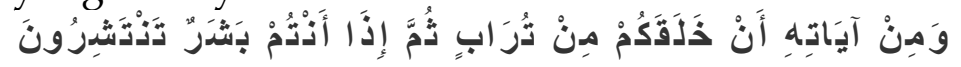

Tidakkah kamu perhatikan sesungguhnya Allah Telah menundukkan untuk (kepentingan) mu apa yang di langit dan apa yang di bumi dan menyempurnakan untukmu nikmat-Nya lahir dan batin. Dan di antara manusia ada yang membantah tentang (keesaan) Allah tanpa ilmu pengetahuan atau petunjuk dan tanpa kitab yang memberi penerangan.(Qs. Al-rum : 20)

Demikian pula dalam ayat lain disebutkan yang artinya :

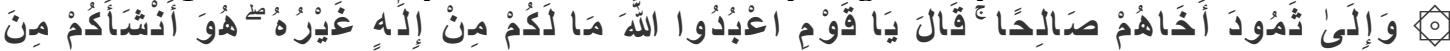

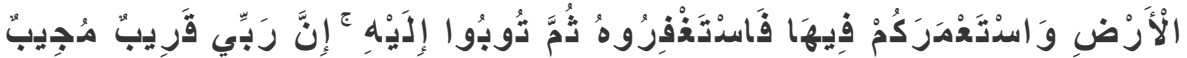

Dan kepada Tsamud (kami utus) saudara mereka shaleh, shaleh berkata: "Hai kaumku, sembahlah Allah, sekali-kali tidak ada bagimu Tuhan selain Dia. Dia telah menciptakan, kamu dari bumi (tanah) dan menjadikan kamu pemakmurnya [726], karena itu mohonlah ampunan-Nya, kemudian bertobatlah kepada-Nya sesungguhnya Tuhanku amat dekat (rahmat-Nya) lagi memperkanankan (doa hamba-Nya)."(Qs.Hud :61)

Maksudnya: manusia dijadikan penghuni dunia untuk menguasai dan memakmurkan dunia. Dan dalam firman Allah lain yang Artinya :

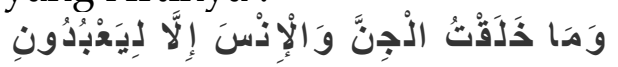

Dan Aku tidak menciptakan jin dan manusia melainkan melainkan supaya mereka mengabdi kepada-Ku.(Qs. Al-Dzariat :56)

Dan pada ayat lain yang artinya :

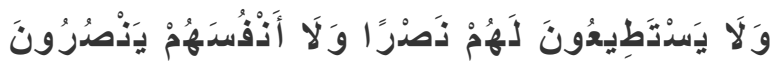

Dan berhala-berhala itu tidak mampu memberi pertolongan kepada penyembahpenyembahnya dan kepada dirinya sendiripun berhala-berhala itu tidak dapat memberi pertolongan.(Qs.al-'araf :192)

Selanjutnya disebutkan pula dalam ayat lain yang artinya :

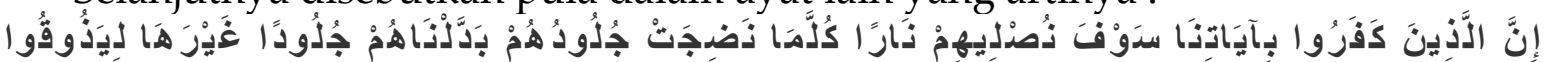

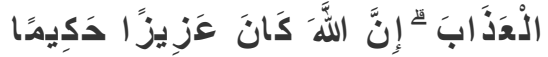

Sesungguhnya orang-orang kafir kepada ayat-ayat kami, kelak akan kami masukkan mereka ke dalam neraka. Setiap kali kulit mereka hangus, kami ganti kulit mereka dengan kulit yang lain, supaya mereka merasakan azab. Sesungguhnya Allah Maha Perkasa lagi Maha Bijaksans.(Qs. Al-Nisa' : 56)

Lalu dalam ayat lain yang artinya :

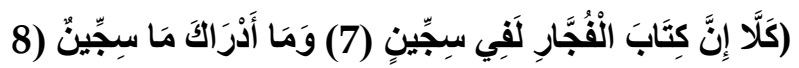


RAUDHAH Proud To Be Professionals Jurnal Tarbiyah)damiyah

Volume 3 Nomor 2 Edisi Desember 2018

P-ISSN : 2541-3686

Yang telah menciptakan kamu lalu menyempurnakan kejadianmu dan menjadikan (susunan tubuh)mu seimbnag, dalam bentuk apa saja yang dia kehendaki, dia menyusun tubuhmu.

\section{(Qs. Al-Muthaffifin : 7-8)}

Adapun unsur tanah/bumi menyebabkan manusia memiliki fungsi dalam hidupnya sebagai khalifah dimuka bumi, sebagaimana firman-Nya yang artinya :

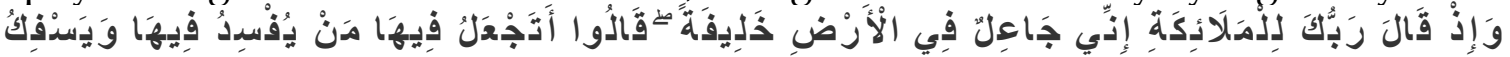

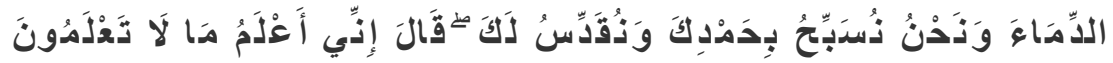

Ingatlah ketika tuhanmu berfirman kepada para malaikat : "Sesungguhnya ku hendak menjadikan seorang khalifah di muka bumi". mereka berkata: "mengapa engkau hendak menjadikan (khalifah) di bumi itu orang yang akan membuat kerusakan padanya dan menumpahkan darah, padahal kami senantiasa bertasbih dengan memuji engkau dan mensucikan?" Tuhan berfirman: "Sesungguhnya Aku mengetahui apa yang tidak kamu ketshui."(Qs. Al-Baqarah: 30)

Yaitu jabatan yang Allah berikan kepada manusia untuk mengatur, memelihara dan memakmurkan bumi atas nama Allah, sedang adanya unsur ruh/langit dalam diri manusia, maka manusia juga memiliki tugas dan kewajiban dalam hidup untuk beribadah kepada Allah, maka dengan bersatunya unsur tanah dan langit, jasad dan ruh dalam diri manusia, juga dengan kedudukannya sebagai khalifah disertai dengan tugas dan kewajiban "Beribadah kepada Allah" maka manusia adalah makhluk yang dimuliakan Allah dari makhluk lainnya, sebagaimana ayat berikut ini yang artinya :

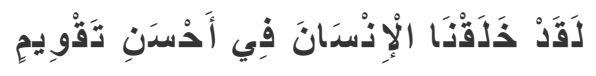

Sesungguhnya kami telah menciptakan manusia dalam bentuk yang sebaik-baiknya(Qs. AlThien : 4)

\section{Tujuan Hidup}

Sebagimana telah dikemukakan diatas, bahwa manusia lahir ke dunia ini bukan atas kehendak sendiri, tetapi semata-mata iradah (kehendak) Allah swt. Pada saat manusia dilahirkan ke alam ini, dia tidak tahu apa-apa (laata'lamuuna syaida).jangankan mengetahui tujuan hidupnya, tahu tentang siapa dirinya, orang tuanya, dan tempat hidupnya pun setelah bersosialisasi dengan orang tuanya (orang lain).

Manusia dalam naturnya ingijn melanjtkan hidupnya, tetapi dalam usahausaha melanjutkan hidup itu, ia senantiasa menghadapi tantangan-tantangan yang acapkali merepukan bahaya-bahaya, apakah itu dalam bentuk bencana alam; seperti banjir, angin topan, kemarau dan lain-lain dalam bentuk penyakit, ataupun dalam bentuk maut, terhadap hal-hal ini manusia merasa dirinya lemah dan ingin mencari tempat berlindung dan tempat meminta tolong untuk kesejahteraan dan 


\section{Memakmurkan Bumi dalam Perspektif Teologi Pendidikan Husnul Amin}

keselamatan dirinya. Dalam hal ini agamalah yang dianggap dapat memberi petunjuk dan jalan yang harus ditempu untuk keselamatan dirinya itu ${ }^{2}$.

Bagi orang yang tidak mau mengenal atau membenci agama (seperti orangorang ateis), tujuan hidup didunia ini baginya adalah misteri, sesuatu yang tidak jelas, baik arah maupun wujudnya, sehingga akhirnya dia mengalami kehidupan yang sesat. Sigmund freud, seorang psikonalisis yang ateis mengatakan bahwa wujud hidup manusia adalah kematian (di dunia ini).

Agar manusia hidupnya tidak sesat, maka agama meberikan petunjuk kepada manusia, tentang apa sebenarnya tujuan hidup di dunia ini dalam hal ini, islam menjelaskan bahwa tujuan hidup manusia di dunia ini tiada lain adalah " mardhaatillah" (untuk mencari ridho allah). Untuk mencapai tujuan ini adalah dengan taqwa atau beriman dan beramal shalih (beribadah kepada Allah), seperti tercantum dalam firman Allah SWT dalam al- Quran ${ }^{3}$ yang artinya:

Sesungguhnya orang-orang yang beriman dan mengerjakan amal sholeh mereka itu adalah sebaik-baik makhluk. 8). Balasan mereka disisi tuhan mereka ialah surga 'adn yang mengalir dibawahnya sungai-sungai; mereka kekal didalamnya selama-lamanya. Allah ridhp terhadap mereka dan mereka pun ridho kepadanya. Yang demikian itu adalah (balasan) bagi orang yang takut pada Tuhannya".

Menurut Achmadi, tujuan utama penciptaan manusia adalah pertama, agar manusia beribadah kepada Allah swt sebagaimana yang tercantum dalam QS Az Zariyat: 56. Maka ibadah dalam islam adalah tunduk dan patuh sepenuh hati kepada Allah. Pengertian ibadah sangat luas, meliputi segala amal perbuatan yang titik tolaknya ikhlas kepada Allah, tujuannya keridhlaan Allah, garis amalnya saleh. Ibadah tidak akan mengurangi prestasi kerja seseorang hamba, tetapi justru akan memperoleh nilai tambah yang sangat bebas artinya, baik bagi dirinya sendiri maupun bagi lingkungannya, karena segala perbuatannya dilandasi dengan motivasi luhur yang terkait dan terikat dengan zat Yang Maha Tinggi.

Tujuan kedua, adalah manusia diciptakan sebagai wakil Allah di muka bumi (QS Al-Baqarah: 30, Yunus: 14 dan Al-An'am: 165). Karena Allah zat yang menguasai dan memelihara alam semesta (Rabbul 'alamin) maka maka tugas utama manusia sebagai wakil Tuhan ialah menata alam sebaik-baiknya untuk memakmurkannya untuk kesejahteraan hidupnya.

Tujuan ketiga, manusia diciptakan untuk membentuk masyarakat manusia yang saling kenal-mengenal, hormat menghormati dan tolong menolong antara satu dengan yang lain (QS al-Hujurat: 13). Kalau tujuan penciptaan yang pertama dan kedua lebih difokuskan pada tanggung jawab individu, maka tujuan penciptaan yang ketiga ini menegaskan perlunya tanggung jawab bersama dalam menciptakan kemakmuran dunia dan tatanan kehidupan dunia yang damai. ${ }^{4}$

\footnotetext{
${ }^{2}$ Harun Nasution, Islam Rasional; Gagasan dan Pemikiran. Bandung; Mizan 1995, Hal. 80.

${ }^{3} \mathrm{Al}$ Quran Karim Surat al-Bayyinah [98] ayat 7-8 dan terjemahannya

${ }^{4}$ Achmadi, Ideologi Pendidikan Islam, Paradigma Humanisme Teosentris, Yogyakarta: Pustaka Pelajar, 2005, halaman 61-63
} 


\section{Tujuan dan Fungsi Hidup}

Orang islam memahami bahwa hidup di dunia ini mempunyai tugas yang jekas, yaitu beribadah kepada Allah swt. Tugas ibadah ini sebagaimana tercantum dalam al-Quran ${ }^{5}$ sebagai berikut:

“ Dan Aku tidak menciptakan jin dan manusia melainkan supaya mereka mengabdi kepadaku".

Pelaksanaan tugas ibadah ini amat terkait dengan fungsi hidup manusia di dunia ini, yaitu sebagai "hamba Allah" (Abdullah) dan "khalifah Allah" (Khalifahtullah). Sebagai hamba Allah orang islam menyadari bahwa dirinya mempunyai kewajiban untuk mengabdi, bertaqarrub atau beribadah langsung kepadanya (hablum minaullah), melalui ibadah mahdhah (ibadah ritual-personal, seperti : sholat, saum, dan berdoa), dan ibadah ghair maghdah (ibadah sosial, yaitu ibadah kepada Allah melalui hablum minannas, yang dalam pelaksanaannya melalui fungsi sebagai khalifah Allah).

Sebagai khalifah Allah, orang islam menyadari bahwa dirinya mengemban amanah atau tanggung jawab (responsibility) untuk mewujudkan misi suci kemanusiaannya sebagai " rahmatan lil 'alamin" (rahmat bagi seluruh alam). Upaya yang ditempuh untuk mewujudkan misi tersebut adalah dengan senantiasa berinisiatif dan berpastisipasi aktif dalam menciptakan tatanan kehidupan masyarakat yang nyaman, sejahtera, dan jalinan persaudaraan serta kasih sayang antar sesama, dan berupaya mencegah terjadinya pelecehan nilai-nilai kemanusiaan, penindasan terhadap kaum mustadl'afin (kaum lemah, miskin, atau orang-orang yang marjinalkan) dan pengrusakan lingkungan hidup (baik lokal, regional maupun global) ${ }^{6}$.

Kewajiba untuk menciptakan kemakmuran dimuka bumi ini termaktub dalam al Quran7, sebagai berikut:

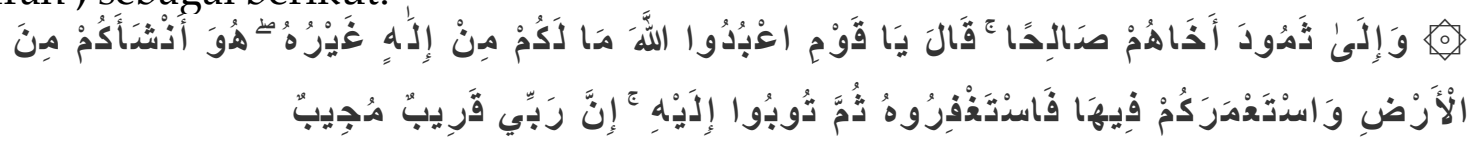

"... Dia telah menciptakan kamu dari bumi (tanah) dan menjadikan kamu pemakmurnya...".

\footnotetext{
${ }^{5}$ Al-Quran Karim Surat al-Dzariyat [51] ayat 56 dan terjemahannya

${ }^{6}$ Yusuf Syamsu, Psikologi Belajar Agama (Perspektif Agama Islam), Bandung Pustaka Bani Quraisy, 2005, halaman 18

${ }^{7}$ Al-Quran Karim surat Al-Huud [11] ayat 61 dan terjemahannya
} 


\section{Memakmurkan Bumi dalam Perspektif Teologi Pendidikan Husnul Amin}

\section{Manusia dan pemakmuran bumi}

Dari pemaparan di atas jelas sudah bahwa manusia adalah makhluk yang diciptakan diata fitrah islam, ia tidak akan pernah menjadi malaikat yang tercipta dari cahaya namun ia juga bukan iblis yang tercipta dari api. Betapa pun ia tercipta dari tanah liat atau air hina, akan tetapi Allah menghendaki agar ia menjadi makhluk yang mulia dan mukallaf artinya yang dibebani, sebagai makhluk yang telah di istimewakan dengan berbagai macam kelebihan, manusia tidak dibiarkan tanpa tugas dan tanggung jawab. Nikmat penciptaan dan berbagai kelebihan itu harus di syukuri dengan melakukan ibadah secara benar. Potensi besar yang diberikan Allah kepadanya itu juga dimaksudkan agar ia mampu mengelolah bumi ini, mewakili Allah mengatur kehidupan sesuai yang dikehendakinya. Sebagai khalifah ia tidak boleh bertindak sekehendaknya.

Sehubungan dengan tugas manusia untuk ist'marul ardhi, maka akan lebih baik jika kita mengupas kalimat tersebut agar pemahaman kita lebih mendalam.

Kalimat استعمارadalah ism masdar ghairu mi-mi, yang madhi-nya adalah استعرر, dan ia merupakan mazid dengan tiga huruf yaitu: $ت, \omega$, l, yang mengandung arti طلنpermintaan dan anjuran, dimana mujarrad dari kalimat mut'addiyah, yakni kalimat yang membutuhkan maf'ul bihi (ini secara bahasa), kalimat mujarrad ini ada

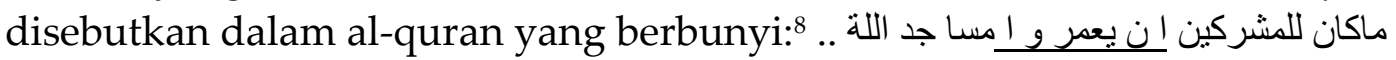

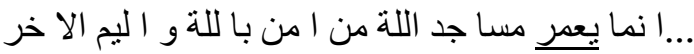

Artinya : tidaklah orang-orang musyrik itu mau memakmurkan masjid-masjid Allah... sesungguhnya orang-orang yang memakmurkan masjid hanyalah mereka yang beriman kepada Allah dan hari akhir.....

Adapun kalimat mazidnya yakni ستعمر-يستعمر IAllah sebutkan dalam al-Quran yang berbunyi :

$$
\text { مو انشا كم من ال ال ر ض و ا ستعمر كم فيها (هؤ د : } 61
$$

Yang artinya : “... Dia telah menciptakan kamu dari bumi (tanah) dan menjadikan kamu pemakmurnya.."

Dengan demikian bisa disimpulkan bahwa isti'ma-rul Ardh adalah upaya yang harus dilakukan manusia untuk mengelolah fasilitas yang Allah berikan di muka bumi demi kemakmuran dunia dan kemajuan hidupnya.

Karena manusia adalah khalifah yang ditugaskan untuk memakmurkan bumi, dan mendapat kepercayaan untuk mewakili kekuasaannya dibumi. Sebagai khalifah (wakil) ia haru memperhatikan beberapa prinsip berikut :

1. Tidak memiliki kekuasaan hakiki

Pada hakikatnya kepemilikan dan kekuasaan itu bukan milik manusia karena pemilik dan penguasa yang hakiki adalah Allah, pencipta alam semesta. Ditangan Allah segala kerajaan langit dan bumi. Manusia hanya mendapat amanah untuk mengelolahnya.

2. Bertindak sesuai kehendak yang mewakilkan.

\footnotetext{
${ }^{8}$ QS.Al-Taubah ayat 17-18
} 
Karena ia bukan pemilik dan penguasa yang hakiki, maka ia bertidak hanya sesuai kehendak pihak yang mewakilkan kepadanya yaitu Allah SWT.

3. Tidak melampaui batas.

Tindakan wakil yang menyimpang dan melampaui batas-batas yang dikehhendaki pihak yang mewakilkan adalah penghianatan.

Peristiwa-peristiwa yang melanda tanah air tercinta akhir-akhir ini, adalah merupakan akibat dari penghianatan sebagian manusia terhadap apa yang Allah amanahkan kepadanya, akan tetapi banyak pula hal-hal yang telah di upayakan sebagian manusia dimuka bumi ini sebagai khalifatullah fil ardhi dari penemuanpenemuan terbaru yang sangat berguna bagi kehidupan manusia.

Maka dalam rangka mengemban tugas mengelola sumber daya alam semesta dan selanjutnya menciptakan kesejahteraan di muka bumi ini, Allah swt memberikan sarana dan alat yang sangat diperlukan oleh manusia. Sarana itu kemudian disebut dengan Hidayah.

Menurut Syaikh Ahmad Musthafa al-Maraghi dalam tafsirnya membagi hidayah kepada beberapa bagian, yakni hidayah berupa gharizah (insting), hawasi (inderawi), akal, agama, maunah dan tawfiq9.

Sarana atau alat dari upaya pemakmuran dunia yang dimaksud di atas juga mencakup ilmu pengetahuan, tanpanya, maka manusia akan keliru dalam mengelola falitas yang Allah sediakan untuknya.

Menurut pandangan al Quran, ilmu ditinjau dari sisi memperolehnya terdiri dari dua macam. Pertama,ilmu yang diperoleh tanpa upaya manusia, disebut ilmu laduni, seperti yang diisyaratkan antara lain oleh al Quran ${ }^{10}$ yang artinya:

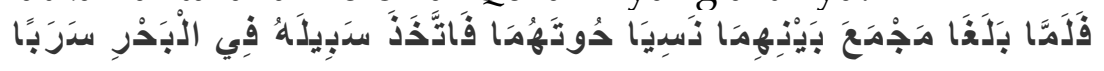

"Lalu mereka bertemu dengan seorang hamba diantara hamba-hamba kami, yang telah kami berikan kepadanya rahmat dari sisi kami, dan yang telah kami ajarkan kepadanya ilmu dari sisi kami"

Kedua, ilmu yang diperoleh karena usaha manusia, yang disebut ilmu kasbi. Ayat-ayat yang berkaitan dengan ilmu kasbi ini jauh lebih banyak bertebaran dalam al Quran dan hadis nabi SAW dari pada yang berkaitan dengan ilmu laduni.

Ilmu kasbi itu tidak begitu saja datang pada manusia. Untuk memperoleh ilmu, manusia harus belajar dan atau mengajar dalam suatu sistem yang disebut pendidikan.

Manusia berpendidikan yang berkualitas merupakan prasyarat untuk mendapat melaksanakan peranannya sebagai khalifah Allah di bumi. Kualitas manusia menunjukan tingkat baik dan buruk, tinggi dan rendahnya sumber daya manusia (SDM). Karena tujuan penciptaan manusia untuk diperankan sebagai khalifah Allah dibumi, maka Allah telah mempersiapkan berbagai potensi insani atau sumber daya manusia untuk dikembangkan secara optimal sehingga menjadi manusia berkualitas dan mampu melaksanakan peran kekhakifahan untuk

\footnotetext{
${ }^{9}$ Nunu Burhanuddin, Al-Quran, Kitab Sosial, Yogyakarta: Interpena,2009, hal.17-22.

${ }^{10} \mathrm{Al}$-Quran Karim Surat Al-Kahfi [18] Ayat 65 dan Terjemahannya.
} 


\section{Memakmurkan Bumi dalam Perspektif Teologi Pendidikan Husnul Amin}

memakmurkan bumi, memakmurkan bumi bukan dalam arti yang sempit, tapi dalam arti yang sangat luas, yaitu upaya mengelola fasilitas alam, sumber daya alam dan sumber daya manusia di segala bidang, seperti bidang pertanian dengan menemukan alat-alat yang canggih untuk memperbaiki produksi, dan pengembangan ilmu pertanian melestarikan lingkungan, penghijauan alam dengan penanaman hutan yang telah gundul, melarang illegal logging dll. Demikian pula pada sector pendidikan, dengan mengadakan penemuan-penemuan dunia terbaru didunia pendidikan, baik system pembelajaran, kurikulum, peningkatan sarana dan prasarana, mencetak SDM yang handal mengadakan school finance dan lain-lain yang kesemuanya diperuntukan untuk kemakmuran dunia.

Dalam mencetak manusia yang siap memakmurkan bumi, maka quraisy shihab mendiskripsikan 4 sumber daya manusia yang harus digunakan dan dikembangkan yaitu:

1. Daya tubuh, yang mengantarkan manusia berkekuatan fisik berfungsinya organ tubuh dan panca indera berasal dari daya ini;

2. Daya hidup yang menjadikan manusia memiliki kemampuan mengembangkan dan menyesuaikan diri dengan lingkungannya, serta mempertahankan hidup dalam menghadapi segala tantangan;

3. Daya akal yang memungkinkan manusia memiliki ilmu pengetahuan dan teknologi;

4. Daya kalbu, yang memungkinkan manusia bermoral, merasakan keindahan kelezatan iman, dan kehadiran tuhan ${ }^{11}$.

Apabila keempat SDM tersebut digunakan dan dekembangkan secara baik, maka kualitas manusia akan mencapai puncaknya, yaitu pribadi yang beriman, berbudi pekerti luhur memiliki kecerdasan, ilmu pengetahuan dan keterampilan, keuletan serta wawasan masa depan yang disrtai dengan fisik yang sehat, dengan SDM yang handal seperti ini, sangat dimungkinkan manusia sebagai Khalifah dimuka bumi ini akan benar-benar mengemban amanah Allah dalam rangka mengelola segala fasilitas yang Allah amanahkan kepadanya, lantaran dia mengelolanya dengan ilmu pengetahuan.

Namun apabila manusia menghianati amanah ke khalifahan dengan tidak merpengetahuan dalam mengelola fasilitas Allah sehingga berdampak kepada kerusakan-kerusakan, maka sesungguhnya manusia telah mencampakkan dirinya dalam kehinaan. Penghianatan tersebut merupakan tindakan yang sangat melampaui batas, bahkan al Quran menyamakan mereka dengan makhluk-makhluk yang lebih rendah darinnya ${ }^{12}$. Diantaranya:

1. Seperti hewan ternak (al-'Araf : 179, al-Furqon : 43-44)

2. Seperti anjing (al-'Araf :176)

3. Seperti kera (al-Maidah : 60)

4. Seperti kayu (al-Munafiqun : 4)

\footnotetext{
${ }^{11}$ Achmad, Ideologi Islam; Paradigms Humanisme Teosentris, Yogyakarta: Pustaka Pelajaran, 2005, hal. 108109.

${ }^{12}$ Op Cit, Hal. 164 
RAUDHAH Proud To Be Professionals Jurnal Tarbiyah)damiyah

Volume 3 Nomor 2 Edisi Desember 2018

P-ISSN : 2541-3686

5. Seperti babi (al-Maidah :60)

6. Seperti batu (al-Baqarah : 74)

7. Seperti laba-laba (al-Ankabut : 41)

8. Seperti keledai (al-Jumu'ah : 5)

\section{Simpulan}

Kehadiran manusia dimuka bumi ini, tiada lain adalah untuk beribadah kepada Allah. Allah menciptakan manusia agar melakukan pengabdian kepadanya, diantaranya kewajiban memakmurkan dunia di mana manusia telah Allah anugerahkan berbagai macam saran berupa sumber daya alam yang terhampar di muka bumi ini untuk dikelolahnya.

Agar terwujud tugas pemakmuran dunia yang maksimal, maka dibutuhkan sumber daya manusia yang terdidik, dan cara satu-satunya adalah dengan pendidikan, diperlukan pendidikan untuk menompang kualitas sumber daya tersebut, selanjutnya manusia pada akhirnya mampu memajukan dunia, memakmurkan dunia dengan memunculkan penemuan-penemuan yang baru, dan itu telah terbukti dengan berbagai macam lembaga-lembaga pendidikan dengan berbagai macam bentuk dan berbagai macam disiplin ilmu. 


\section{Memakmurkan Bumi dalam Perspektif Teologi Pendidikan}

Husnul Amin

\section{DAFTAR PUSTAKA}

Al-Qur'anul Karim dan Terjemahannya

Hadis Nabi Muhammad SAW.

Jasiman, Syarah Rasmul Bayan Tarbiyah, Surakarta: Aulia Press Solo, Cet.1 , 2005

Achmadi, Ideologi Pendidikan Islam; Paradigma Humanisme Teosentris, Yogyakarta: Pustaka Pelajar, 2005.

Burhanuddin, Num, Al-Qur'an, Kitab Sosial, Yogyakarta: Interpena, 2009

Jalaluddin, Teologi Pendidikan, Jakarta: PT Raja Grafindo Persada, 2002

K.H.M Taib Thahir Abdul Muin, Ilmu Kalam, Jakarta: Widjaya, 1986

Muchsin, Bashori dan Abdul Wahid, Pendidikan Islam Komtemporer, Bandung: PT Refika Aditama, 2009.

Nasution, Harun. Islam Rasional; gagasan dan pemikiran. Bandung: Mizan 1995.

Yusuf, Syamsu, Psikologi Belajar Agama (Perspektif Agama Islam), Bandung; Pustaka Bani Quraisy, 2005.

Zakaria, Aceng, Pokok-Pokok Ilmu Tauhid, Garut: Ibn Azka Press, 2005 